\title{
Immunotherapy of COVID-19 with poly (ADP-ribose) polymerase inhibitors: starting with nicotinamide?
}

\author{
Abdulla Badawy ${ }^{1}$ \\ ${ }^{1}$ Cardiff Metropolitan University
}

July 17, 2020

\begin{abstract}
Background and purpose: COVID-19 induces a proinflammatory environment that is stronger in cases requiring intensive care. Overexpression of the aryl hydrocarbon receptor (AhR) by COVID-19 may activate nuclear poly (ADP-ribose) polymerase 1 (PARP 1) thereby inducing cell death by NAD+ and ATP depletion. The purpose of this review is to propose PARP 1 inhibition as a COVID-19 therapy, starting with nicotinamide. Experimental approach: Evidence for the above effects of COVID-19, other coronaviruses and lung conditions will be reviewed. Key results: A proinflammatory environment characterises all the above conditions irrespective of severity. The AhR is overexpressed by various coronaviruses, the pneumovirus respiratory syncytial virus (RSV) and in chronic obstructive pulmonary disease (COPD) patients. PARP 1 is overexpressed in COPD and possibly also asthmatic patients. Conclusions: It is almost certain that PARP 1 is overexpressed by COVID-19. A sequence of events involving PARP 1 and culminating in patient mortality is proposed. PARP 1 inhibition should be the focus of COVID-19 therapy. Potent PARP 1 inhibitors are undergoing trials in cancer, but the highly desirable biochemical and activity profiles of the NAD $(\mathrm{P})+$ precursor and PARP 1 inhibitor nicotinamide justify its use, initially in conjunction with standard clinical care or combined with other agents, and subsequently as an adjunct to stronger PARP 1 inhibitors (once their efficacy is proven) or other therapies. Implications: Preventing death from COVID-19 infection with a widely available vitamin-like substance with a unique biochemical and activity profile can present a great clinical advance worldwide.
\end{abstract}

\section{Hosted file}

Text.pdf available at https://authorea.com/users/337816/articles/470364-immunotherapy-ofcovid-19-with-poly-adp-ribose-polymerase-inhibitors-starting-with-nicotinamide

\section{Hosted file}

Figure 1.docx available at https://authorea.com/users/337816/articles/470364-immunotherapyof-covid-19-with-poly-adp-ribose-polymerase-inhibitors-starting-with-nicotinamide

\section{Hosted file}

Figure 2.docx available at https://authorea.com/users/337816/articles/470364-immunotherapyof-covid-19-with-poly-adp-ribose-polymerase-inhibitors-starting-with-nicotinamide

\section{Hosted file}

Figure 3.docx available at https://authorea.com/users/337816/articles/470364-immunotherapyof-covid-19-with-poly-adp-ribose-polymerase-inhibitors-starting-with-nicotinamide 